\title{
Insurers' Investment in Infrastructure: Overview and Treatment under Solvency II
}

\author{
Nadine Gatzert and Thomas Kosub \\ Department of Insurance Economics and Risk Management, Friedrich-Alexander-University Erlangen-Nuremberg, \\ Lange Gasse 20, Nuremberg 90403, Germany. \\ E-mails: nadine.gatzert@fau.de; thomas.kosub@fau.de
}

The financial market environment poses serious challenges for insurance companies to provide stable returns on a long-term basis, as particular traditional asset classes are currently characterised by generally low interest rates and high volatility. Against this background, the aim of this paper is to study infrastructure investments from an insurer's perspective. In particular, based on a categorisation of different types of infrastructure investments, we provide an overview of main characteristics along with risks and chances. In addition, the treatment of different infrastructure investments under Solvency II regulations is studied, which can have a considerable impact on an insurer's asset management decisions. The study shows that the attractiveness of infrastructure investments strongly depends on the type of investment and its treatment under Solvency II and that considerable risks can be involved.

The Geneva Papers (2014) 39, 351-372. doi:10.1057/gpp.2013.34

Keywords: infrastructure; Solvency II; capital requirements; performance

Article submitted 05 July 2013; accepted 04 November 2013; published online 19 February 2014

\section{Introduction}

Against the background of the current financial market environment with low interest rates and volatile stock markets, infrastructure investments are increasingly discussed in the insurance industry. Allianz, for instance, recently decided to invest in parking metres in Chicago, ${ }^{1}$ while in January 2013, Munich Re announced an investment in wind parks in France, aiming to diversify their portfolio with sustainable investments presenting manageable risks and attractive returns. ${ }^{2}$ However, the benefits and detriments of infrastructure investments strongly depend on the type of investment structure (e.g. (project) bonds, loans, equity or funds), which may differ tremendously and can thus not be generalised. ${ }^{3}$ In addition, especially for insurers, the attractiveness of infrastructure investments is further impacted by their treatment under Solvency II, the new European risk-based capital regulation for insurers planned to be introduced sometime after 2016. Hence, the aim of this paper is to provide an overview of different ways of investing in infrastructure along with the main characteristics and risks, and to study the treatment of these different types from an insurer's perspective under Solvency II.

\footnotetext{
${ }^{1}$ www.allianz.com/de/presse/news/finanzen/beteiligungen/news_2012-02-01.html, accessed 6 December 2012.

${ }^{2}$ www.meag.com/reddot/html/de/unternehmen/up_peressemitteilungen_7557.asp, accessed 10 Feburary 2013.

${ }^{3}$ See, for example, Beeferman (2008); Inderst (2010); Rothballer and Kaserer (2012).
} 
With increasing privatisation and deregulation of national property since the 1980s and an increasing investment gap expected by the OECD ${ }^{4}$ until 2030, infrastructure investments can be expected to provide important opportunities for private and institutional investors over the next decades. ${ }^{5}$ As a result of the financial crisis in 2007/2008, many regulatory changes in the credit business for infrastructure have also been made. Debt ratios have been lowered and, therefore, existing infrastructure projects, which until now have been mainly financed by debt, now require new capital to assure the projects' funding. This deleveraging process will presumably lead to an increased demand for equity capital and increase the investment volume of infrastructure investments in the future. Finally, due to recent innovations and research on renewable energy, energy infrastructure especially will require substantial amounts of capital to replace old energy facilities with new solar and wind power energy systems. For insurers seeking new investment alternatives, especially the stability of long-term cash flows plays a major role along with the question of how different infrastructure investment types are treated under Solvency II.

In the literature, Inderst ${ }^{6}$ provides an overview of investment characteristics regarding different infrastructure vehicles, risk-return profiles as well as historical performance, emphasising the heterogeneity of this asset class. A literature review with a focus on infrastructure equity investments is provided by Blanc-Brude, ${ }^{7}$ while Severinson and Yermo ${ }^{8}$ discuss the impact of changes of accounting standards and Solvency II on an insurer's asset allocation. In addition, several papers conduct empirical analyses, typically focusing on single investment types. ${ }^{9}$ Overall, the academic literature so far has mainly dealt with empirical questions and thereby often focused on single, specific infrastructure investment types (e.g. private equity or infrastructure stocks and funds). In this paper, we aim to focus on the insurer's perspective by first providing a comprehensive overview of different ways to invest in infrastructure along with their main characteristics, performance and risks, and then studying the treatment under Solvency II. We thereby differentiate between equity, debt and funds, as well as between direct and indirect investments.

The remainder of this paper is structured as follows. The next section provides a categorisation of infrastructure investments along with a discussion of performance and risks. Based on this, the subsequent section exhibits the treatment under Solvency II, and the final section concludes.

\section{Infrastructure investments: Characteristics and market overview}

\section{Definition of infrastructure}

There is no clear or unique definition of infrastructure in general. 10 "Investable" infrastructure is typically focused on material infrastructure as laid out in Table $1 .^{11}$ The sectors

\footnotetext{
${ }^{4}$ OECD (2006).

${ }^{5}$ Beyerle et al. (2011, p. 5).

${ }^{6}$ Inderst (2010).

${ }^{7}$ Blanc-Brude (2013).

${ }^{8}$ Severinson and Yermo (2012).

${ }^{9}$ See, for example, Bitsch et al. (2010) for the case of private equity, Peng and Newell (2007) and Finkenzeller et al. (2010) regarding listed and unlisted infrastructure funds and equity, and Rothballer and Kaserer (2012) for global listed infrastructure stocks.

${ }^{10}$ Bitsch et al. (2010, pp. 110, 113); Inderst (2009, pp. 6-7).

${ }^{11}$ See, for example, EIOPA (2013a, p. 33), Inderst (2010, p. 72).
} 
Table 1 Sectors available as material infrastructure investments

\begin{tabular}{ll}
\hline Economic infrastructure & Sectors and subsectors \\
\hline Transport & Ground: Roads, rails, bridges, tunnels, parking \\
& Air: Airports \\
& Water: Canals, ports \\
& Energy supply \\
Utilities (energy and disposal) & Generation, transmission, distribution: oil and gas, district heating, water \\
& Disposal: Waste, sewage water, storage, recycling \\
& Cable networks \\
Transmission \\
Satellites \\
Radio tower \\
\\
Renewable energy & Police force, prisons \\
\hline Social infrastructure & Hospitals, diagnostics \\
\hline
\end{tabular}

transport, utilities (energy and disposal), communication and renewable energy are mainly classified as economic infrastructure, while social infrastructure includes, for example, hospitals, schools and police stations. ${ }^{12}$

\section{Investing in infrastructure}

The main global investors in infrastructure funds are public pension funds (19 per cent), private sector pension funds (17 per cent), banks (10 per cent) and insurance companies ( 8 per cent) ${ }^{13}$ Hereby, besides the already mature Australian and U.K. markets, especially the Central European countries are maturing, thus offering new investment opportunities.

In general, one needs to distinguish several stages when investing in infrastructure projects: Planning, construction, operation and winding-up. ${ }^{14}$ In particular, during the early years (planning and construction), investors have negative cash flows due to high capital requirements and then expect high payouts during later years (J-curve effect). ${ }^{15}$ One further differentiation is given by dividing infrastructure investments into "Brownfield" and "Greenfield". 16 "Brownfield" refers to less risky, often already existing infrastructure

\footnotetext{
${ }^{12}$ EIOPA (2013a, p. 33).

13 Preqin (2012, p. 31).

${ }^{14}$ See, for example, EIOPA (2013a, p. 35).

15 See, for example, Inderst (2009, p. 7).

${ }^{16}$ EIOPA (2013a, p. 35).
} 
projects with stable cash flows, where investors need to modernise and renovate facilities and that are more often located in developed markets. ${ }^{17}$ "Greenfield" links to new investments, bearing higher risks but therefore also higher return opportunities for investors, being more characteristic of emerging markets. ${ }^{18}$

When investing in infrastructure, private and institutional investors further have different choices between direct and indirect infrastructure investments that can be listed or unlisted, ${ }^{19}$ which are associated with different characteristics and risks as shown in Table 2, following the Solvency II asset categorisation. Hereby, the simplest way to invest in infrastructure is by purchasing corporate bonds, stocks (corporate equity) or infrastructure funds. Directly investing in infrastructure generally comes along with higher capital needs and higher political and regulatory risks, depending on the concrete investment. Investors can thereby again choose between listed investments such as stocks and bonds of, for example, energy firms, which may show a higher correlation with the general stock market movement, or unlisted investments. The latter can comprise project bonds, project loans or public private partnerships (PPP), for instance, where private or institutional investors can contribute capital and cooperate with the government to build public infrastructure, but depending on the PPP financing model, are not allowed to determine the usage of the infrastructure, as only the state has sovereign functions. As these kinds of investments are directly negotiated, PPP investments are often illiquid, have a long time horizon and need a minimum investment amount. ${ }^{20}$ In general, debt investments such as loan capital can be emitted either by direct loans, project loans or loan securitisation through special purpose vehicles. ${ }^{21}$ In addition, direct infrastructure investments in real estate are possible. Even though real estate in general does not always qualify as an infrastructure investment object, there are still similarities, including the ones listed above, for example, indivisibility, site dependence, long lifecycles and investment horizons, and illiquidity risk. ${ }^{22}$ Furthermore, real estate investments can also involve several default risk factors such as long construction periods, faulty construction or project planning and technological progress.

Funds as an indirect investment, in contrast, can be broadly diversified (across sectors or investment markets) through investing in different infrastructure projects (which can have complex structures and in turn further invest in listed and unlisted infrastructure projects). ${ }^{23}$ This generally implies lower political and regulatory risks as compared with (individual) direct investments if the fund provides sufficient liquidity. However, infrastructure funds can also involve considerable concentration and cluster risks in the case where they have a regional or sector focus in contrast to globally and cross-sector diversified infrastructure funds, for instance. In addition, investments can already be made with smaller amounts of capital. ${ }^{24}$ When comparing listed and unlisted funds, the market for the latter, which are not

\footnotetext{
${ }^{17}$ Page et al. (2008, p. 105); EIOPA (2013a, pp. 35-36); Credit Suisse (2010, p. 2).

${ }^{18}$ Beyerle et al. (2011, p. 6); Credit Suisse (2010, p. 2).

${ }^{19}$ Bitsch et al. (2010, p. 109); Inderst (2009, p. 7f.). See also Beeferman (2008) for a comprehensive categorisation and discussion of differences between infrastructure investment types from the perspective of pension funds.

20 Bitsch et al. (2010, p. 109).

${ }^{21}$ See EIOPA (2013a, pp. 34, 42).

22 Finkenzeller et al. (2010, p. 266).

${ }^{23}$ Beeferman (2008, p. 21); Bitsch et al. (2010, p. 109).

${ }^{24}$ Bitsch et al. (2010, p. 109).
} 
Table 2 Overview and classification of infrastructure investments following Solvency II (EIOPA) and selected empirical results regarding specific characteristics of infrastructure investments

\begin{tabular}{|c|c|c|c|c|c|c|}
\hline Asset class & Specification & Author(s) & $\begin{array}{l}\text { Stable cash } \\
\text { flows }\end{array}$ & $\begin{array}{l}\text { Inflation-hedging } \\
\text { ability }\end{array}$ & $\begin{array}{l}\text { Correlations/ } \\
\text { diversification } \\
\text { potential }\end{array}$ & Performance and risks \\
\hline
\end{tabular}

Direct investment

Bonds Corporate,

government bonds

\begin{tabular}{|c|c|c|c|c|c|}
\hline $\begin{array}{l}\text { Debt financed PPPs, } \\
\text { project bonds }\end{array}$ & $\begin{array}{l}\text { Sawant (2010) } \\
(60 \text { emerging markets } \\
\text { infrastr. project bonds } \\
\text { from } 15 \text { countries })\end{array}$ & $\begin{array}{l}\text { - Yes (but } \\
\text { only visual } \\
\text { inspection: } \\
\text { fairly stable) }\end{array}$ & $\begin{array}{l}\text { - No (possibly due to } \\
\text { sample bonds } \\
\text { having fixed } \\
\text { coupons) }\end{array}$ & $\begin{array}{l}\text { - Low with equities } \\
\text { and commodities }\end{array}$ & $\begin{array}{l}\text { - Low return, low volatility } \\
\text { - Negative Sharpe ratios (returns not } \\
\text { sufficient in light of their risk, unattractive) }\end{array}$ \\
\hline
\end{tabular}

Sirtaine et al.(2005)

(34 PPP concessions

in Latin America,

representative of

global privatisation

trends in Latin
America (on averag

concessions not considerable, sometimes

below cost of capital

in operation for

- Strong variance of returns across

concessions and countries (on average

telecom and energy concessions better than transport and water)

- Variance of returns across concessions

7 years)) partially explained by quality of regulation (the better quality of regulation, the closer the alignment between financial returns and costs of capital)

- But: Potential bias due to economic regulation, incentive to dress down profitability so as not to be penalised at periodic tariff reviews 
Table 2 (continued)

\begin{tabular}{|c|c|c|c|c|c|c|}
\hline Asset class & Specification & Author(s) & $\begin{array}{l}\text { Stable cash } \\
\text { flows }\end{array}$ & $\begin{array}{l}\text { Inflation-hedging } \\
\text { ability }\end{array}$ & $\begin{array}{l}\text { Correlations/ } \\
\text { diversification } \\
\text { potential }\end{array}$ & Performance and risks \\
\hline
\end{tabular}

Direct investment

Loans Corporate loans, project loans, infrastructure

loan securitisation

Equity Listed: corporate equity

\section{(1) Rothballer and \\ Kaserer (2012) (global \\ stocks, 1975-2009)}

(2) Rödel and

Rothballer (2012)

(global stocks,

1973-2009)

\section{Unlisted: private} equity
Bitsch et al. (2010) (363 infrastr. private equity (PE) deals, 311,000 non-infrastr. PE deals)
- No (not more stable than noninfrastr.

deals in the sense of predictable)
- (2) Yes, but only for high pricing power (not significant, only slightly superior than non-infrastr. stocks)

- (2) In general not better than other equity

- Yes (but not stat. significant)

- Not uncorrelated with public equity markets

- Uncorrelated with macroeconomic development
- (1) Lower market risk (beta) than MSCI World (portfolio diversification effects)

- (1) Total corporate risk (volatility of stock returns) not lower

- (1) Significant level of idiosyncratic risk (due to high regulatory and construction risk etc. $=>$ need for well-diversified portfolios of investors)

- (1) High degree of heterogeneity among infrastr. sectors: utilities least risky, followed by transport and telecom

- Duration no longer than non-infrastr. PE deals (but: bias due to funds; duration pressure due to J-curve effect)

- Initial capital requirements significantly higher than non-infrastr. deals

- Lower default rates

- Higher performance/returns (explained by higher market/political risk, higher leverage)

- "Brownfield" (approx. with PE) have lower default rates and higher return than "Greenfield" deals (approx. with venture capital) 


\section{Real estate}

\section{Indirect investment}

Funds Listed

Listed and unlisted
funds (studied jointly,
mixed with stocks):

\section{(1) Peng and Newell}

(2007) (Australian

unlisted funds (5),

UBS infrastr. series as

proxy for listed

infrastr. stocks)

\section{(2) Finkenzeller et al.}

(2010) (Australian

unlisted funds, UBS

index for listed

infrastr. stocks)

(3) Bird et al. (2012)

(Australian listed and

unlisted stocks/funds

and U.S. listed stocks)
- (1) No (but only short time period

considered)

- (2) Yes, but mainly

restricted to

(regulated) utilities

sector
- (1) Low with stock

arket

- (2) Low/moderate

with trad. asset

classes

- (1) unlisted showed lower corr. with other asset classes than listed infrastr.

- (2) significant interinfrastr.-sector

correlations

- (3) no serial corr. (despite illiquidity,

valuation appraisal-

based etc. explained

by noise in data)
- (1)/(3) All infrastr. sectors significantly outperform property, stocks, bonds (in terms of total return)

- (3) But: Large variation depending on sector; regulated assets (e.g. utilities) outperform unregulated assets

- (1)/(2)/(3) Listed infrastr. has higher (highest) risk / volatility and highest return; higher than unlisted funds

- (1) Listed composite infrastr. gave third highest return, outperforming unlisted infrastructure

- (1)/(2) Unlisted infrastr. has lowest volatility among all considered asset classes

Unlisted infrastr. return similar to equity and bonds, lower than property

- (3) Listed infrastr. has higher volatility and higher beta than listed utilities

Unlisted (private equity, hedge funds, alternatives,

commodities) 
traded at a stock exchange, is rather illiquid and, hence, the investment duration is generally longer compared with liquid, listed fund investments.

The characteristics of the investment thus strongly depend on the type of investment (e.g. direct vs indirect, listed vs unlisted) and cannot be simply generalised. However, there are several properties that infrastructure investments typically exhibit (or that are at least expected), but which may differ depending on sector, environment, investment phase, way of investment and the individual project.

In addition, investments in infrastructure projects generally show large economic external effects, since improved or newly constructed infrastructure affects society and the attractiveness of a local area, for instance. This may lead to an inflow of labour force leading to increased tax income and further possible investments in local infrastructure. From an economic perspective, infrastructure shows a low elasticity of demand, that is, price increases for usage of infrastructure or increased fees show low or no effects on infrastructure demand. Furthermore, infrastructure assets such as PPPs (e.g. construction of a highway) are often regulated objects within monopolistic or quasi-monopolistic markets with high barriers to entry, which are thus also assumed to induce inflation-hedging ability. Investments are also often not divisible and have to fulfill minimum investment sizes, as public infrastructure cannot operate at its economic optimum, which also implies that supply and demand are less flexible. $^{25}$

Many infrastructure attributes, such as liquidity risk or the amount of capital needs, have not or have only partially been empirically studied in the scientific literature. In Table 2, we thus present selected empirical results on further (typically desired or expected) characteristics that have been empirically studied in the literature, focusing on stable cash flows and the inflation-hedging ability of infrastructure investments. ${ }^{26}$ In addition, correlations with other asset classes as well as risk and return aspects are presented, which are discussed in more detail in the next subsection.

Particularly the duration of the investment and the stability of the cash flows is one aspect of special relevance for insurance companies, which also depends on the concrete type of infrastructure project. For instance, bond-like infrastructure investments with a large capital investment in the beginning and long-term cash flows over decades are sensitive towards changes in interest rates and can thus be used for duration matching purposes. Hence, for insurers, the integration of infrastructure projects in asset liability management decisions can provide the opportunity to match their long-term liability durations. ${ }^{27}$ Many infrastructure objects exist over long time horizons and, depending on the type of investment, for example, investments with bond-like payout structures, can provide stable cash flows. However, to the best of our knowledge, empirical support for stable cash flows so far only exists for the case of project bonds as shown by Sawant ${ }^{28}$ (see Table 2), which, however, is based on a visual inspection. In the case of private equity project deals, in contrast, Bitsch et al. ${ }^{29}$ do not find support that private equity infrastructure deals provide more stable (in the sense of

\footnotetext{
${ }^{25}$ See Inderst (2009, pp. 6-7); Li and Li (2013, p. 51).

${ }^{26}$ A literature review with focus on infrastructure equity is also given in, for example, Blanc-Brude (2013).

${ }^{27}$ See Inderst (2010, p. 81); European Commission (2013, p. 9).

28 Sawant (2010).

${ }^{29}$ Bitsch et al. (2010).
} 
"predictable") cash flows using a cash flow variability measure that accounts for different durations and time-dependent means of cash flows.

In the case where the investor holds pricing power for the infrastructure object cash flows, the investment performance is assumed to hedge against inflation by adjusting prices. While for project bonds, Sawant ${ }^{28}$ does not find empirical support for an inflation-hedging ability (possibly due to fixed coupons), empirical support has been provided by Rödel and Rothballer $^{30}$ for global listed infrastructure stocks, whereby the inflation-hedging ability was mainly restricted to sectors with strong pricing power and, in addition, only slightly superior to the inflation-hedging ability of non-infrastructure stocks. Infrastructure equities in general, however, do not hedge inflation better than non-infrastructure equities. ${ }^{31}$ The authors explain their findings by (1) restrictions in the monopolistic pricing power of infrastructure firms and an increasing competitiveness; (2) the fact that cost-based regulatory regimes dominate incentive-based regimes in most infrastructure sectors, whereby the former does not necessarily provide a hedge against inflation, and (3) an inflation exposure on the cost side, among others. Similarly, Bird et al. ${ }^{32}$ also provide evidence for the inflationhedging ability of infrastructure investments in the U.S. and Australian markets for stocks and fund investments within the (regulated) utility sector only. As their data set is an updated set of the one used in Peng and Newell, ${ }^{33}$ the fact that the latter did not find support for an inflation-hedging ability could be explained by the short time period that is considered in their analysis. For the case of private equity project deals, Bitsch et al. ${ }^{29}$ find support for an inflation-hedging ability (but not statistically significant).

Thus, as infrastructure investments are very heterogeneous and can differ in many ways, there is also some discussion about whether infrastructure investments can be classified as an own, stand-alone asset class at all. ${ }^{34}$

\section{Performance of infrastructure investments}

The heterogeneity of infrastructure investments also becomes apparent when considering the selected empirical results regarding performance and risks as exhibited in the right column of Table 2. In general, empirical analyses regarding the financial performance of infrastructure fund investments are often subject to restrictions as data is limited; for example, in the case of funds, the majority was launched only after $2004 .{ }^{35}$ Owing to the general lack of data, most studies have been conducted for the case of listed stocks as well as listed and unlisted funds, especially for the mature Australian market (see Table 2), where sufficient data is available and which cannot be simply generalised to other markets, but still provides an important indication of performance and risks.

Regarding listed corporate equity, Rothballer and $\mathrm{Kaserer}^{36}$ find that infrastructure equity has a significantly lower market risk (beta) than comparable equities in the MSCI World

\footnotetext{
${ }^{30}$ Rödel and Rothballer (2012).

${ }^{31}$ See Rödel and Rothballer (2012, p. 117).

32 Bird et al. (2012).

${ }^{33}$ Peng and Newell (2007).

${ }^{34}$ See Massing and Pick (2011, p. 622); Bird et al. (2012, p. 2).

35 See Preqin (2012, p. 29); Massing and Pick (2011, p. 622).

${ }^{36}$ Rothballer and Kaserer (2012).
} 
360

index but that total corporate risk (volatility of stock returns) is not lower compared with other public equities, suggesting a significant level of idiosyncratic risk, which the authors explain by the high political and regulatory risks associated with infrastructure investments, among others, and which also implies that investors should have a well-diversified portfolio. They also find a high degree of heterogeneity across different sectors.

For the case of unlisted private equity infrastructure deals, Bitsch et al. ${ }^{29}$ show that unlisted infrastructure private equity investments exhibit higher returns ${ }^{37}$ and are uncorrelated to the macroeconomic development (but not uncorrelated to public equity markets). The authors thereby explain higher returns of infrastructure private equity deals by the higher market and political risk as well as higher leverage. At the same time, capital requirements are considerably higher at inception of the project. The authors also show that the duration of infrastructure deals is no longer than the duration of non-infrastructure deals, which may be ascribed to a bias in funds caused by the J-curve effect, that is, the duration pressure caused by negative cash flows in the first two-three years, followed by at least one cycle of five years for rapidly increasing cash flows. ${ }^{38}$ In addition, infrastructure deals exhibit lower default frequencies as compared with non-infrastructure private equity deals, whereby "Brownfield" investments (approximated with private equity deals) have higher returns and lower default rates than "Greenfield" investments (approximated with venture capital deals).

The lower default rates of infrastructure investments can also be confirmed in the case of project bonds as laid out in the study (with a restricted sample size) by $\mathrm{S} \& \mathrm{P}^{39}$ regarding historical annual default rates, which shows that the general infrastructure project bond default rate for 2003-2009, for instance, lies between 0.5 and 2 per cent, whereas the default rate for corporate bonds for the identical time period is between 1 and 5.5 per cent. Regarding project loans, a study by Moody's ${ }^{40}$ shows that 10 -year cumulative default rates of infrastructure investments (excluding the telecom and power sectors) are low investmentgrade/high speculative credit-grade, being speculative grade during the construction phase in the first two project years and less risky in later years of the operation phase. In addition, ultimate recovery rates are higher the later the default occurs, averaging approximately 80 per cent and even 100 per cent in two-thirds of the cases. Overall, the infrastructure sector still proved to be the least risky, but without including the (more risky) media \& telecom and power sectors.

In this context, the empirical study by Sawant ${ }^{28}$ based on 60 emerging markets project bonds from 15 countries shows that the considered infrastructure project bonds exhibit a generally unattractive risk return profile, having a negative Sharpe ratio with low risk but also low returns. ${ }^{41}$ Similar results have been found for PPP (private infrastructure) concessions by Estache and Pinglo ${ }^{42}$ and Sirtaine et $\mathrm{al}^{43}$ in the case of Latin America,

\footnotetext{
${ }^{37}$ Using a sample of 7,453 investments made in 81 countries by 254 PE firms (1971-2005), Lopez-de-Silanes et al. (2011) find a median IRR of 21 per cent gross of fees. In addition, the authors find that one in ten investments goes bankrupt and that one-fourth have an IRR of above 50 per cent.

${ }^{38}$ See also Page et al. (2008) with reference to Probitas Partners (2007).

${ }^{39}$ S\&P (2010, p. 4).

${ }^{40}$ Moody's (2013).

${ }^{41}$ See Sawant (2010, p. 82).

${ }^{42}$ Estache and Pinglo (2004).

${ }^{43}$ Sirtaine et al. (2005).
} 
where returns were sometimes even below the cost of equity, whereby on average, telecom and energy concessions were better than transport and water as found by Sirtaine et al. ${ }^{43}$ The authors also found highly volatile returns across concessions, sectors and countries, whereby the variance of returns could partly be explained by the quality of regulation. In particular, for higher regulatory quality, financial returns were closer to the cost of capital, thus emphasising the need for high quality regulation.

Regarding listed and unlisted infrastructure funds, in contrast, different studies (mainly using Australian unlisted funds and listed equity, partly also including stocks in their analysis) show that all infrastructure sectors outperform property, stocks and bonds in terms of total return, for instance. ${ }^{44}$ However, large variations were found depending on the respective sector. Bird et al., ${ }^{32}$ for instance, show that the regulated utilities sector generally outperformed other, unregulated assets. In addition, listed infrastructure was shown to have a higher (or the highest) risk (in terms of volatility) and the highest return, also outperforming unlisted infrastructure. ${ }^{45}$ Furthermore, unlisted infrastructure had the lowest volatility among all considered asset classes and, especially, was also lower than listed infrastructure. ${ }^{46}$ The returns of unlisted infrastructure were thereby similar to bonds, but lower than property. For the listed Australian infrastructure and utilities sector, the authors further find (by visual inspection when accounting for certain factors, see Bird et al., ${ }^{32}$ p. 19) a declining trend in the three-year rolling excess returns, which the authors explain by increasing rents of managers, which undermines net returns.

One further major aspect is the diversification potential of infrastructure assets, that is, the correlation with other asset classes. Here, Sawant ${ }^{28}$, for instance, showed that the correlation of infrastructure project bonds is low with equities and commodities, thus providing diversification potential. In the case of unlisted private equity deals, as described above, Bitsch et $a .^{29}$ do not find support that cash flows are uncorrelated with public equity markets, but that they are uncorrelated with macroeconomic development. In regard to listed and unlisted infrastructure funds and stocks, a generally low correlation with the stock market and other traditional asset classes was found (see Table 2). In addition, unlisted infrastructure funds showed a lower correlation with other asset classes than listed infrastructure (stock), thus representing better opportunities for diversifying a portfolio. Finally, significant inter-infrastructure-correlations were found by Finkenzeller et al. ${ }^{47}$

Apart from the empirical findings in the scientific literature, information about performance and risks are also provided in studies from the industry. According to Credit Suisse, ${ }^{48}$ the risk-return profile of "Brownfield" investments can thereby be classified between fixed income and equity investments, whereby "Greenfield" infrastructure investments exhibit considerably larger risk-return variations than investments in classical equity, for instance. Performance data presented in the Preqin ${ }^{49}$ Global Infrastructure Report includes 108 unlisted infrastructure funds and provides vintage information on funds from 1993 to 2008 along with their net internal return rates (IRR). The report shows that funds established from

\footnotetext{
44 See Peng and Newell (2007); Bird et al. (2012).

45 See Peng and Newell (2007); Bird et al. (2012); Finkenzeller et al. (2010).

${ }^{46}$ See Peng and Newell (2007); Finkenzeller et al. (2010).

${ }^{47}$ Finkenzeller et al. (2010).

${ }^{48}$ Credit Suisse (2010, p. 2).

${ }^{49}$ Preqin (2012).
} 
362

1993 to 1999 have a median net IRR of 9 per cent in the overall period (up to 2012), whereas younger funds from 2000 to 2005 exhibit a median of 21.1 per cent. The general target IRR of unlisted infrastructure funds according to $\operatorname{Preqin}^{49}$ (p. 29) is approximately in line with the figures listed in Page et al. ${ }^{50}$ with reference to Probitas Partners ${ }^{51}$ where "Brownfield" investments exhibit an expected IRR of 10-12 per cent and "Greenfield" investments have an expected IRR of 15 per cent and more. According to Inderst ${ }^{6}$ (p. 80), however, pension funds as investors, for instance, typically assume lower figures, using an expected return of $9-10$ per cent and a volatility of 7-8 per cent.

In addition to regulatory and political risks, as infrastructure projects influence regions, further risks and chances can rise due to external effects, which can be both positive and negative. Hence, investors have to analyse each investment not only quantitatively, but also based on a qualitative risk assessment approach. However, as large investment projects have long building and maintenance periods, an accurate forecast regarding external effects as well as internal project cash flows are highly challenging. In this context, Blanc-Brude (with focus on "public" infrastructure) points out the relevance of contractual features regarding risk and return, which may be even more important than the specific type of investment. In addition, for fund investments, concentration or cluster risks of infrastructure projects can emerge from similar infrastructure investments within the fund's investment portfolio. ${ }^{52}$ Such cluster risks could evolve from, for example, a fund specialised on regional investments such as roads in a certain regional area that could at the same time be affected by natural catastrophes. Finally, infrastructure projects are often long-term projects which imply the risk of innovation.

In summary, a performance measurement of infrastructure investments including concrete risk-return profiles can indeed be obtained in the case of listed investments. However, even in these cases, one needs to study the composition of the considered index or fund to identify possible concentration effects regarding individual stocks or a geographic focus (BlancBrude, $^{7}$ p. 41). For other investments forms, particularly for unlisted or illiquid investment, a quantitative risk assessment is not easily possible due to illiquidity risk, regulatory and political risks, valuation risk, as well as innovation and technological risks. In these cases, investors need to conduct an adequate qualitative risk assessment.

\section{Infrastructure investments under Solvency II}

The global infrastructure project investment volume in 2011 amounted to 405 billion USD with the majority in loans ( 328 billion USD $=81$ per cent), followed by equity ( 62 billion USD $=15$ per cent), and infrastructure bonds ( 16 billion USD $=4$ per cent)..$^{53}$ Regarding loans, for instance, according to EIOPA,${ }^{54}$ insurers increasingly provide direct long-term lending as banks are reducing their activities partly due to Basel III or may even buy portfolios of infrastructure loans from banks in the future. In particular, apart from direct

\footnotetext{
${ }^{50}$ Page et al. (2008, p. 105).

${ }^{51}$ Probitas Partners (2007).

52 Inderst (2010, pp. 80-81).

53 EIOPA (2013a, pp. 36-37).

${ }^{54}$ EIOPA (2013a, p. 36).
} 
issuance of loans, insurers can also hold loans via transfer of credit claims from banks to insurers by means of loan securitisation, for instance. With respect to equity, EIOPA ${ }^{53}$ points out that this amounts to less than 5 per cent in Europe, but with a growing trend in regard to unlisted infrastructure funds, which provide less volatile returns (see Table 2). Finally, even though infrastructure project bonds make up only a minor part of the total infrastructure investment volume, EIOPA ${ }^{55}$ sees chances by way of the Europe 2020 Project Bond Initiative, for instance, ${ }^{56}$ which is intended to provide credit enhancement by means of guarantees. Hence, for insurers, the question generally arises as to which type of infrastructure investment is attractive against the background of their business model and the regulatory environment.

In this context, particularly Solvency II, the new European regulatory framework for insurance companies planned to be in force sometime after 2016, is one major key driver for or against investments in infrastructure assets due to the risk-based capital requirements imposed by the new system. The higher the capital requirement, the less attractive is the investment in general. Solvency II requires an adequate assessment of risks associated with asset investments and, hence, in the case of infrastructure investments, the amount of capital requirements will strongly depend on the respective investment type as shown in the previous section (see Table 2). The quantitative capital requirements are thereby prescribed in Solvency II's Pillar 1 and can be derived either using the standard model provided by the regulatory authorities, or an internal model that more adequately reflects the company's individual risk situation. The relevant risk measure is the value at risk for a 99.5 per cent confidence level.

In case of the Solvency II standard model, different risk categories need to be aggregated in order to calculate the overall solvency capital requirement (SCR). In the following, we focus on the market risk module, which contains seven submodules that need to be aggregated. ${ }^{57}$ Of main relevance in the context of infrastructure investments are thereby the equity, interest rate, spread and property risk submodules. The SCR for each submodule is given by the change in the net asset value (NAV) arising from a shock or stress, whereby the $N A V$ is defined as the difference between assets $A$ and liabilities $L$ :

$$
\Delta N A V=\max (N A V-(N A V \mid \text { shock }), 0)=\max ((A-L)-((A-L) \mid \text { shock }), 0) .
$$

In the case of equity investments, for instance, a shock of 39 per cent for "type 1" equity, that is, companies listed in the EEA or OECD, is required (without symmetric adjustment against pro-cyclical effects according to the fifth Quantitative Impact Study (QIS5); 30 per cent with adjustment), which implies an SCR of 39 per cent. Investments in "type 2" equity, that is, companies outside of the EEA or OECD, have higher capital requirements of 49 per cent (40 per cent with adjustments). Strategic participations are charged with 22 per cent and investments in real estate generally have a risk capital of 25 per cent.

When calculating the SCRs for bonds (loans in principle are to be treated similarly, see EIOPA $^{55}$ ), the market risk submodules for interest rate and spread risk have to be taken into account. The SCR for spread risk for one bond thereby depends on the duration of the bond and the shock depending on the bond's rating. The SCR for interest rate risk refers to all assets sensitive to changes in the term structure and is derived by the difference between the present value of the bond without and with shock. In the following, the SCR calculations are

\footnotetext{
55 EIOPA (2013a).

56 European Commission (2013, p. 12).

${ }^{57}$ Directive 2009/138/EC, p. 125.
} 
illustrated for the case of bonds, focusing only on the asset side for simplicity, that is, the $N A V$ only refers to the value of assets. The SCR for spread risk $s p$ for one bond $i$ is thus given by

$$
M k t_{s p}^{\text {bonds }}=\max (\Delta N A V \mid \text { spread shock } ; 0)=\max \left(M V \cdot \text { duration } \cdot F^{u p}(\text { rating }) ; 0\right),
$$

where $M V$ denotes the market value of the bond, duration refers to the modified Macaulay duration and $F^{u p}$ denotes the shock depending on the bond's rating. ${ }^{58}$

The SCR for interest rate risk int refers to all assets sensitive to changes in the term structure and is derived by

$$
M k t_{i n t}=\max \left(M k t_{\text {int }}^{u p}, M k t_{\text {int }}^{\text {down }}\right),
$$

where $M k t_{i n t}^{u p}=P V_{i n t}-P V_{i n t}^{u p}$, that is, the difference between the present value $\left(P V_{\text {int }}\right)$ of the bond without and with upward shock $\left(P V_{i n t}^{u p}\right)$ given by

$$
P V_{\text {int }}^{u p}=\sum_{t=1}^{T} \frac{C F(t)}{\left(1+r_{f}(t) \cdot\left(1+s^{u p}(t)\right)\right)^{t}}, T=\max (t \mid C F(t) \neq 0),
$$

where $C F(t)$ denotes the cash flow in period $t, r_{f}$ refers to the risk-free rate given by the regulator, and $s^{u p}$ the upward adjustment of the term structure. ${ }^{59}$

The aggregation of the modules is done using the so-called square-root formula,

$$
S C R_{m k t}^{S I I}=\sqrt{\sum_{i n t, s p} \operatorname{CorrMkt}_{i n t, s p} \cdot M k t_{i n t} \cdot M k t_{s p}} .
$$

Figure 1 shows how credit rating and maturity changes of the bond investment impact capital requirements for spread risk with $C_{\text {orrMkt }}{ }_{\text {int, sp }}=0$ (only up-shock scenario). One can also observe that diversification effects between the two submodules (spread and interest rate risk) imply a strong reduction in the SCR for the market risk module.

However, when deriving the SCR and when making investment decisions, insurers need to take both assets and liabilities into account. For instance, especially for life insurers, both assets and liabilities are sensitive towards changes in interest rates (bond investments on the asset side, discounting life insurance cash flows on the liability side), such that a duration mismatch results in a non-simultaneous increase of assets and liabilities due to interest rate stress. This may increase capital requirements, as assets generally have a shorter duration than life insurance liabilities and the latter react stronger towards interest rate shocks. Hence, by means of long-term infrastructure investments with long durations, the duration mismatch can be considerably reduced. Particularly important here are direct project finance (by means of bonds, loans and equity), infrastructure investment funds (listed and unlisted) as well as infrastructure loan securitisation vehicles. $^{60}$

Thus, depending on the type of infrastructure investment (see Table 2 for a categorisation), SCRs can strongly differ and Table $3^{61}$ summarises the treatment of different infrastructure

\footnotetext{
${ }^{58}$ CEIOPS (2010, pp. 121-123).

${ }^{59}$ CEIOPS (2010, p. 111).

60 EIOPA (2013a, p. 35).

${ }^{61}$ See Directive 2009/138/EC; EIOPA (2013a, p. 41).
} 
a
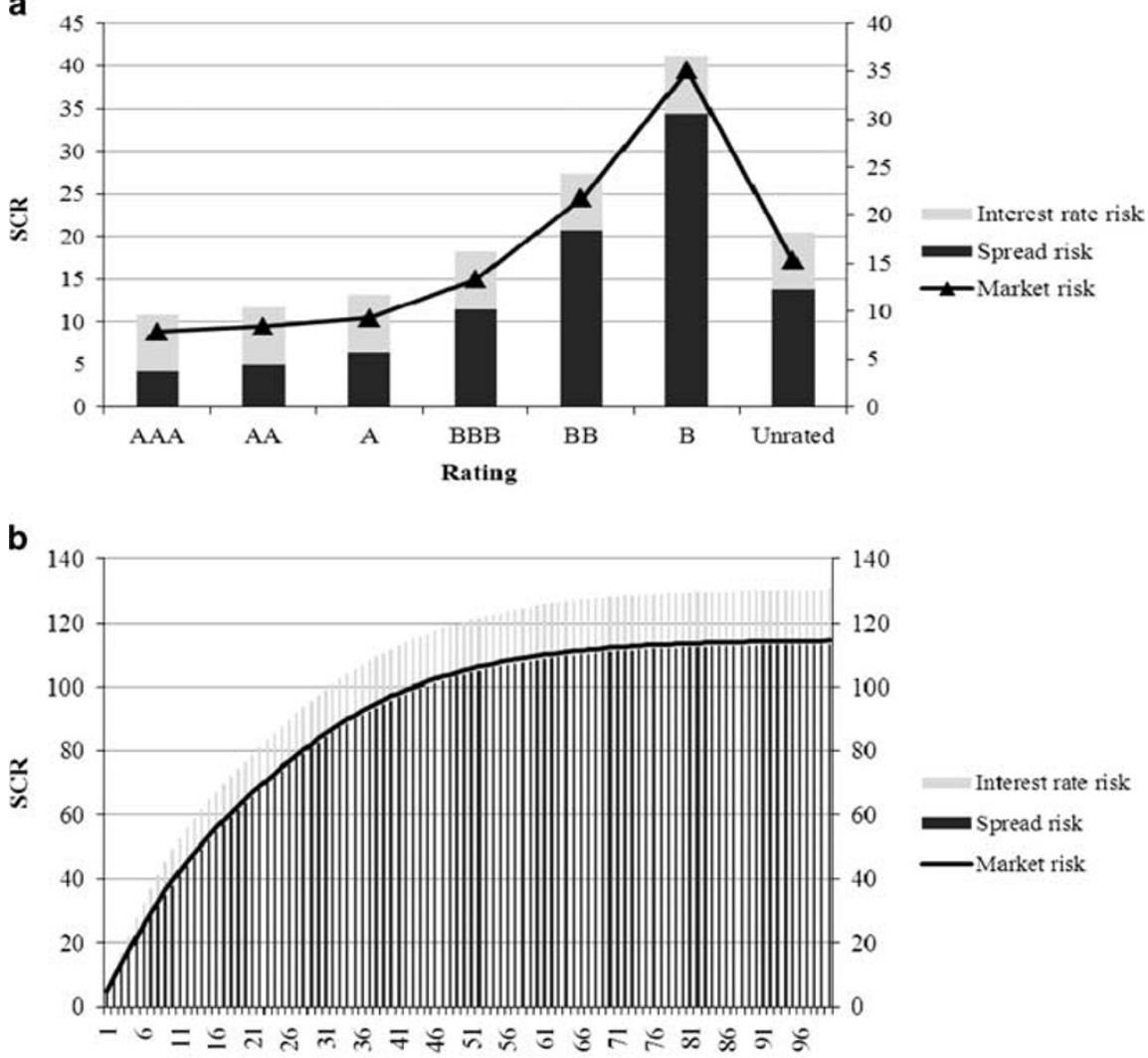

Maturity

Figure 1. Exemplary derivation of the SCR for market risk (aggregated based on spread and interest rate risk submodules using the square-root formula) for a bond with different ratings and maturities under the Solvency II standard model (asset side only). (a) SCR for different ratings (coupon: $3.0 \%$; maturity: 5 years; face value: 100; market value: 100); (b) SCR for different maturities (coupon: $3.0 \%$; rating: BB; face value: 100; market value: 100$)$.

investment categories under the Solvency II standard model as specified in QIS5 along with the Solvency II asset classification and the main risks relevant for SCR. In particular, as reflected in Table 3, EIOPA ${ }^{55}$ sees corporate infrastructure debt (corporate bonds, project bonds and loans) and listed stocks to behave similar to other non-infrastructure corporate debt and equity and thus not to introduce separate risk classes, even though there may be considerable differences depending on the sector for the different types of investments (see Table 2), which may be taken into account when using a partial internal model.

As laid out in Table 3, bond investments are mainly affected by interest risk and spread risks within the market risk module (see also Figure 1). While corporate bonds, non-EEA government bonds or debt financed (project) bonds differ in their SCRs according to their bond rating and maturity, EEA government bonds require 0 per cent capital according to 
Table 3 Infrastructure investments under the Solvency II standard model

\begin{tabular}{|c|c|c|c|c|c|}
\hline $\begin{array}{l}\text { Asset } \\
\text { class }\end{array}$ & Specification & Example & Solvency II classification & Main risks & Solvency capital requirements \\
\hline \multirow[t]{4}{*}{ Bonds } & Corporate bonds & Bond of E.ON SE & Corporate bonds & $\begin{array}{l}\text { Interest rate risk, } \\
\text { spread risk }\end{array}$ & Dependent on rating and maturity \\
\hline & \multirow[t]{2}{*}{ Government bonds } & $\begin{array}{l}\text { Transportation infrastructure } \\
\text { bonds }\end{array}$ & EEA government bonds & $\begin{array}{l}\text { Interest rate risk, } \\
\text { spread risk }\end{array}$ & $0 \%$ \\
\hline & & - & Non-EEA government bonds & $\begin{array}{l}\text { Interest rate risk, } \\
\text { spread risk }\end{array}$ & Dependent on rating and maturity \\
\hline & $\begin{array}{l}\text { Debt financed PPPs, project } \\
\text { bonds }\end{array}$ & $\begin{array}{l}\text { New South Wales (Australia) } \\
\text { Waratah Annuity Bond }\end{array}$ & Bonds & $\begin{array}{l}\text { Interest rate risk, } \\
\text { spread risk }\end{array}$ & Dependent on rating and maturity \\
\hline Loans & $\begin{array}{l}\text { Corporate loans, project loans, } \\
\text { infrastructure loan securitisation }\end{array}$ & - & Loan capital & $\begin{array}{l}\text { Interest rate risk, } \\
\text { spread risk }\end{array}$ & Dependent on rating and maturity \\
\hline \multirow[t]{5}{*}{ Equity } & \multirow[t]{3}{*}{ Listed: equity } & Shares of E.ON SE & Type 1 equity (EEA/OECD) & Equity risk & $39 \%$ \\
\hline & & Shares of Reliance Ind. Ltd. & Type 2 equity (non-EEA/OECD) & Equity risk & $49 \%$ \\
\hline & & - & $\begin{array}{l}\text { Banks and financial services } \\
\text { providers }\end{array}$ & Equity risk & $0 \% / 100 \%^{\mathrm{a}}$ \\
\hline & $\begin{array}{l}\text { Unlisted: private equity/ project } \\
\text { equity }\end{array}$ & $\begin{array}{l}\text { Investment in wind park as project } \\
\text { equity }\end{array}$ & Type 2 equity & Equity risk & $49 \%$ \\
\hline & Strategic participation & $\begin{array}{l}\text { Listed and unlisted private, } \\
\text { project or corporate equity }\end{array}$ & Strategic participation & Equity risk & $22 \%$ \\
\hline $\begin{array}{l}\text { Real } \\
\text { estate }\end{array}$ & Real estate & $\begin{array}{l}\text { Investment in local school } \\
\text { building }\end{array}$ & Real estate & Property risk & $25 \%$ \\
\hline \multirow[t]{2}{*}{ Funds $^{\mathrm{b}}$} & Listed & - & "Look through approach" & $\begin{array}{l}\text { "Look through } \\
\text { approach" }\end{array}$ & $\begin{array}{l}\text { Depends on investment, see } \\
\text { categories above }\end{array}$ \\
\hline & $\begin{array}{l}\text { Unlisted (private equity, hedge } \\
\text { funds, alternatives, commodities) }\end{array}$ & - & "Look through approach" & $\begin{array}{l}\text { "Look through } \\
\text { approach" }\end{array}$ & $\begin{array}{l}\text { Depends on investment, see } \\
\text { categories above }\end{array}$ \\
\hline
\end{tabular}

${ }^{\mathrm{a}}$ Participations in banks and financial service providers require no risk capital for market risk, but are directly excluded from own funds, which thus reduces the amount of available capital by 100 per cent of the participation's value. ${ }^{62}$

' If listed or unlisted funds do not provide sufficient information on the investments of the fund itself, thus not allowing the application of the "look through approach", funds are classified as "type 2" equity (49 per cent). 
the standard model. ${ }^{63}$ One example of a bond-equivalent financial instrument is "transportation/traffic infrastructure project bonds", which should classify as infrastructure EEA government bonds. ${ }^{64}$ Such a bond emitted by the state of Bavaria was discussed by German politicians for infrastructure project financing. In the case of unrated corporate and non-EEA government bonds, the spread shock to be taken into account in the calculation of the SCR amounts to 3 per cent with a duration cap of 12 years, thus implying higher capital requirements (see Figure 1(a)). Note in this context that one general problem specifically associated with infrastructure project bonds is the proper calibration at the 99.5 per cent confidence level (value at risk) due to the lack of large historical data (see also Table 2). ${ }^{65}$

An example for an alternative debt financed investment could be the Australian "annuity-style inflation protected debt instrument" emitted by the New South Wales government, which was "established to fund critical economic and social infrastructure projects across New South Wales". ${ }^{66}$ As discussed before, project loans constitute the majority of the infrastructure investments with an expected increasing involvement of insurers as long-term lenders. ${ }^{67}$ The treatment is planned to be analogous to bonds by using the spread risk submodule, which depends on the duration and external rating of the instrument. Note that, as discussed in the previous section, the infrastructure sector still proved to be the least risky according to a study by Moody's, ${ }^{40}$ but without including the (generally more risky) media \& telecom and power sectors.

In general, SCRs for bonds or loans ceteris paribus increase with higher durations (but with decreasing marginal increase ("kinked approach", see Figure 1(b)), but the SCR can be lowered by a reduced duration mismatch. However, insurers may prefer EEA government bonds for duration matching as these do not involve capital charges as opposed to alternative long-term investments with relatively high charges. Of further relevance in this context is the so called "matching adjustment", ${ }^{6}$ which allows a reduction of the required capital for long-term liabilities that are duration- and cash flow-matched by assets and which is still questionable for certain infrastructure investments. ${ }^{69}$ As this procedure requires strict criteria to be fulfilled, such as, for example, holding assets until maturity, managing them separately and assets being of high quality, that is, BB-rated bonds or above, this might put unrated or low-rated infrastructure bond investments in an unfavourable position.

Unlisted equity investments or private and project equity such as, for example, investments in wind parks, are classified as "type 2" equity within the Solvency II framework

${ }^{62}$ CEIOPS (2010, p. 282).

${ }^{63}$ For a detailed analysis of the quantification of credit risk and market risk, see Gatzert and Martin (2012).

${ }^{64}$ See www.csu.de/kommission/wirtschaft/aktuelles/144511247.htm, accessed 18 January 2013 (in German: "Verkehrsinfrastrukturanleihen").

65 EIOPA (2013a, p. 41).

${ }^{66}$ See New South Wales Government (NSW) (2012): www.waratahbonds.nsw.gov.au, accessed 13 Feburary 2013. Note that New South Wales has an AAA rating by the three major credit rating agencies (www.treasury. nsw.gov.au/NSW).

${ }^{67}$ EIOPA (2013a, p. 42).

68 The matching adjustment or premium is the spread between the risk-free rate and the yield of the assets in the portfolio, deducting the expected loss due to default or downgrade of the assets. The matching premium has to be higher than 75 per cent of the long-term average of the spread over the risk-free rate of assets of the same duration and the held assets have to be at least BBB rated (see EIOPA, 2013b).

${ }^{69}$ www.risk.net/insurance-risk/news/2204971/german-insurers-warn-of-solvency-ii-threat-to-infrastructureinvestment, accessed 05 June 2013. 
and thus require a risk capital of 49 per cent without adjustments. EIOPA ${ }^{55}$ defines project equity as an investment that does not give a right to fixed payments, but rather returns consisting of dividend payments or sales proceeds at the expiration date. ${ }^{70}$ Similar to project bonds, direct project equity (and infrastructure loans) may suffer from insufficient data to calibrate the SCRs, especially due to missing market values and the problems associated with reported NAVs. Furthermore, an approximation by means of other indices is highly difficult due to the high degree of heterogeneity of the asset class and the dependence on the respective sector (see Tables 1 and 2). ${ }^{71}$

Real estate investments induce a capital requirement of 25 per cent and investment funds are evaluated via the "look-through" approach, whereby the economic substance of each fund is examined by assessing the underlying assets the fund is invested in. ${ }^{72}$ As such fund investments often cannot be "looked through", the SCRs are set to 49 per cent. However, even with a classification as "type 1" equity, the risk of infrastructure investments may not be reflected entirely correct, as according to industry reports, the actual investment performance may often be categorised similar to "property" products. ${ }^{73}$ In addition, as shown in Table 2, unlisted funds in mature infrastructure markets such as Australia may generally imply a lower risk as compared with other asset classes and also listed funds.

As can be seen, the treatment of infrastructure investments under Solvency II differs considerably depending on the type of infrastructure investment, which will directly impact an insurer's asset portfolio decisions. In particular, especially insurers with low capital buffers may shift their assets from unlisted and illiquid investments towards investments with lower SCRs such as, for example, EEA government bonds. ${ }^{74}$ In addition, exploiting diversification effects between asset classes will become increasingly important. Especially in the case of infrastructure projects, the consideration of diversification should also include the different stages of the investment (e.g. construction and operation) as well as contract design (impacting cash flows) and potential regulatory and political risks associated with the investment. ${ }^{75}$ Hence, as the current version of the Solvency II standard model does not distinguish between different infrastructure sectors and investment types, a partial internal model may be beneficial in order to better reflect the true risk situation and more adequately capture diversification effects associated with infrastructure investments. However, one problem regarding partial internal models (and the standard model) is the potential lack of data, which may prevent a proper calibration at the 99.5 per cent level.

Still, there is some (yet not much) empirical literature, as laid out in the previous section, which indicates certain desirable characteristics for specific infrastructure investment types, which can be taken into account in a partial internal model. This may include the outperformance of infrastructure funds and private equity investments as compared with traditional asset classes, which, however, also depends on the respective sector and the maturity of the infrastructure market as well as whether the investment is "Brownfield" or "Greenfield", for instance. Especially in case of unlisted infrastructure funds, potentially

\footnotetext{
${ }^{70}$ EIOPA (2013a, p. 37).

${ }^{71}$ EIOPA (2013a, pp. 49-50).

72 CEIOPS (2010, p. 109).

${ }^{73}$ Page et al. (2008, p. 105).

${ }^{74}$ Severinson and Yermo (2012, pp. 31-33).

75 See, for example, Blanc-Brude (2013, p. 62).
} 
lower risks (in terms of volatility) should be taken into account as well as diversification effects due to low correlations with other asset classes (listed and unlisted funds, project bonds) and a lower beta (stocks) as shown in Table 2. Lower risks and diversification benefits can thereby imply a reduction in total SCRs from the market risk module. To reduce the risk exposures of such infrastructure investments through diversification and risk spreading among institutional investors, the European Commission ${ }^{76}$ also suggests pooling of financial resources, for example, by means of long-term investment funds.

In addition, a possible reduction of a duration mismatch by means of long-term investments with stable cash flows and low default rates as in the case of project bonds and loans should be studied carefully, as this can substantially decrease total SCRs arising from the interest rate submodule. Yet, as long as Solvency II favours EEA government bonds, insurers may potentially avoid unattractive long-term infrastructure investments. $^{77}$

However, risks of infrastructure investments such as political and regulatory risks can also be considerable and hardly quantifiable. In addition, liquidity risk may arise. A qualitative risk assessment and thorough risk management thus appear vital when investing in infrastructure, especially in the case of direct investments. Furthermore, a careful contract design is crucial, which, along with regulatory and political risks underlying the respective infrastructure project, play a major role with regard to risk-return profiles. ${ }^{78}$ With PPPs, for instance, lower risks may be involved in case of state involvement or guarantees, which should be studied in detail.

One conclusion is that the standard model is not able (and possibly not intended to, partly due to the lack of available data) to provide a fully adequate picture of individual infrastructure investments, which is why more research is necessary for specific types of investments in certain sectors, such as wind parks, for instance.

\section{Summary}

The aim of this paper is to show the treatment of different infrastructure investment types under Solvency II and to present main characteristics of this heterogeneous asset class, including illiquidity risk, political and regulatory risk, capital needs, time horizon and the existence of duration from an insurer's viewpoint based on a review of empirical literature, whereby the latter focused on stable cash flows, inflation-hedging ability, correlations and performance and risks.

Our study emphasises that the determination of SCRs depends on the Solvency II categorisation of the respective infrastructure investment, which does not further distinguish between, for example, different sectors or the specific investment type (e.g. PPP or project bond), even though these investments may not have the same risk. Investing in unlisted equity-like infrastructure or listed "type 2" equity, which includes, for example, wind parks as well as shares in non-EEA stocks, are currently generally associated with capital requirements of up to 49 per cent. Bond-like structures or real estate investments generally

\footnotetext{
${ }^{76}$ European Commission (2013, p. 10).

${ }^{77}$ For example, Severinson and Yermo (2012, pp. 4-5, 32).

${ }^{78}$ See, for example, EIOPA (2013a, p. 39); Blanc-Brude (2013, p. 60).
} 
370

exhibit lower SCRs (but still 25 per cent in the case of real estate, for instance) and can be used for duration matching purposes in an insurer's portfolio, thus having the potential to reduce overall SCRs. Overall, our analysis shows that a partial internal model may be beneficial to better account for actual risks and specific characteristics of certain infrastructure investments. This may include diversification effects (due to low correlations between listed and unlisted infrastructure funds or stocks with other asset classes) and lower market risk (in the case of infrastructure stocks). For instance, especially unlisted infrastructure funds in the mature Australian market showed considerably lower risks as other asset classes including listed infrastructure funds.

However, as infrastructure investments are often investment projects in regulated and monopolistic markets, political and regulatory frameworks have to be taken into account in an accurate way when making investment decisions. In particular, insurers need to gather detailed risk-return information about their preferred (infrastructure) investments. However, since risk and return may not be easily quantifiable due to insufficient data or nonquantifiable risks such as political, regulatory, innovation and technological risks, infrastructure investments need to be assessed individually, using a comprehensive qualitative risk assessment approach in addition to a quantitative risk study. Classical performance measurement cannot be conducted in all cases and challenges arise in terms of valuation and the risk assessment of such often (highly) illiquid investments, which also concerns the adequate derivation of SCRs and the calibration at the 99.5 per cent level. Hence, investors seeking stable and long cash flows should be advised to analyse and monitor their investments carefully.

The decision to invest in infrastructure will also strongly depend on whether SCRs adequately reflect the risks inherent in the respective investment. Otherwise, insurers may be forced to withdraw capital from any inadequately or unclassified infrastructure investments. Presumably this would not only negatively affect insurer's investments, but also national infrastructure construction and maintenance in general. However, associated risks of infrastructure investments may be considerable and more research is necessary to determine adequate SCRs and to study risk-return profiles, gathering more data, thereby clearly distinguishing between the various types of investment possibilities and infrastructure sectors as well as their exposure to regulatory and political risk.

\section{Acknowledgements}

The authors would like to thank two anonymous referees for valuable comments and suggestions on an earlier version of this paper.

\section{References}

Beeferman, L.W. (2008) Pension fund investment in infrastructure: A resource paper, Occasional Paper Series, No. 3, Harvard Law School, December.

Beyerle, T., Voß, O. and Weber, H. (2011) Investitionen in Infrastruktur. Chancen durch die Energiewende in Deutschland, Bonn: IVG-Immobilien.

Bird, R., Liem, H. and Thorp, S. (2012) 'Infrastructure: Real assets and real returns', European Financial Management. doi: 10.1111/j.1468-036X.2012.00650.x. 
Bitsch, A., Buchner, A. and Kaserer, C. (2010) 'Risk, return and cash flow characteristics of infrastructure fund investments', EIB Papers 15(1): 106-137.

Blanc-Brude, F. (2013) Towards efficient benchmarks for infrastructure equity investments, Nice, France: EDHEC-Risk Institute, www.edhec.com, accessed 29 September 2013.

CEIOPS (2010) Quantitative Impact Study 5-Technical specifications, from www.eiopa.europa.eu, accessed 1 October 2012.

Credit Suisse (2010) Can infrastructure investing enhance portfolio efficiency? Credit Suisse Asset Management, from www.credit-suisse.com, accessed 8 October 2012.

EIOPA (2013a) Discussion paper on standard formula design and calibration for certain long-term investments, Frankfurt: EIOPA, from www.eiopa.europa.eu, accessed 5 May 2013.

EIOPA (2013b) Technical findings on the long-term guarantees assessment, Frankfurt: EIOPA, from www.eiopa. europa.eu, accessed 20 June 2013.

Estache, A. and Pinglo, M.E. (2004) Are returns to private infrastructure developing countries consistent with risks since the Asian Crisis? World Bank Policy Research Working Paper 3373.

European Commission (2013) Green Paper-Long-term financing of the European economy, from www.ec.europa. $e u$, accessed 29 September 2013.

Finkenzeller, K., Dechant, T. and Schäfers, W. (2010) 'Infrastructure: A new dimension of real estate? An asset allocation analysis', Journal of Property Investment \& Finance 28(4): 263-274.

Gatzert, N. and Martin, M. (2012) 'Quantifying credit and market risk under solvency II: Standard approach vs. internal model', Insurance: Mathematics and Economics 51(3): 649-666.

Inderst, G. (2009) Pension fund investment in infrastructure, OECD Working Papers on Insurance and Private Pensions 32.

Inderst, G. (2010) 'Infrastructure as an asset class', EIB Papers 15(1): 71-105.

Li, H. and Li, Z. (2013) 'Road investments and inventory reduction: Firm level evidence from China', Journal of Urban Economics 76: 43-52.

Lopez-de-Silanes, F., Phalippou, L. and Gottschalg, O. (2011) Giants at the gate: On the cross-section of private equity investment returns, working paper, EDHEC-Risk Institute, from www.edhec.com, accessed 29 September 2013.

Massing, R. and Pick, W.-D. (2011) 'Infrastruktur-Investments als Bestandteil von Altersvorsorgevermögen', Betriebliche Altersvorsorge. 7/2011: 621-625.

Moody's (2013) Default and recovery rates for project finance bank loans, 1983-2011,from www.moodys.com, accessed 12 May 2013.

OECD (2006) Infrastructure to 2030: Telecom, Land, Transport, Water and Electricity, Paris: OECD Publishing.

Page, S.N., Ankner, W., Jones, C. and Fetterman, R. (2008) 'The risks and rewards of private equity in infrastructure', Public Works Management Policy 13(2): 100-113.

Peng, H.W. and Newell, G. (2007) The significance of infrastructure in investment portfolios. Pacific Rim Real Estate Society Conference, 2007, Fremantile.

Preqin (2012) 2012 Preqin Global Infrastructure Report, from www.preqin.com/, accessed 14 October 2012.

Probitas Partners (2007) Investing in infrastructure funds September 2007, from www.probitaspartners.com/, accessed 01 April 2013.

Rödel, M. and Rothballer, C. (2012) 'Infrastructure as hedge against inflation - Fact or fantasy?', Journal of Alternative Investments 15(1): 110-123.

Rothballer, C. and Kaserer, C. (2012) 'The risk profile of infrastructure investments: Challenging conventional wisdom', Journal of Structured Finance 18(2): 95-109.

S\&P (2010) Recovery: Figuring the recovery rates when global project finance transactions default. Global Credit Portal. RatingsDirect. Standard \& Poor's, from www.standardandpoors.com/, accessed 05 May 2013.

Sawant, R.J. (2010) 'Emerging market infrastructure project bonds: Their risks and returns', Journal of Structured Finance 15(4): 75-83.

Severinson, C. and Yermo, J. (2012) The effect of solvency regulations and accounting standards on long-term investing. implications for insurers and pension funds, OECD Working Papers on Finance, Insurance and Private Pensions, No. 30, from dx.doi.org/10.1787/5k8xd1nm3d9n-en, accessed 29 September 2013.

Sirtaine, S., Pinglo, M.E., Guasch, J.L. and Foster, V. (2005) 'How profitable are private infrastructure concessions in Latin America? Empirical evidence and regulatory implications', Quarterly Review of Economics and Finance 42(2-3): 380-402. 


\section{About the Authors}

Nadine Gatzert studied Mathematics and Economics at the University of Ulm, Germany, and at the University of Southern California in Los Angeles, U.S.A., majoring in Mathematical Finance and Actuarial Science. She received her doctoral degree in 2007 and her postdoctoral qualification in 2009 from the University of St. Gallen, Switzerland. Since 2009, she holds the Chair of Insurance Economics and Risk Management at the FriedrichAlexander-University Erlangen-Nuremberg in Nuremberg, Germany. Her main research interests include enterprise risk management, financial guarantees, alternative risk transfer and solvency regulation in the financial services industry.

Thomas Kosub is a $\mathrm{PhD}$ candidate at the Friedrich-Alexander-University of ErlangenNuremberg, Department of Insurance Economics and Risk Management. He holds a Master of Science in Finance, Auditing, Controlling and Taxation from the University of ErlangenNuremberg. His research interests include infrastructure investments, asset management decisions in insurance companies and Solvency II. 